\title{
Why we did it
}

\section{An account of the driving forces behind the unfolding of human civilization.}

\author{
A Brief History of the Human Race \\ by Michael Cook \\ W. W. Norton: 2003. 384 pp. $\$ 26.95$ \\ Granta: 2004. £20 \\ Melvin Konner
}

Ask the average historian whether a science of history is possible and you are likely to get a condescending smile. History, they assure us, belongs to the humanities; it is not even a social, much less a natural, science. Historiography is an intensely empirical exercise, but it deals with the facts of one time and place, or at most the record of how events have unfolded on a larger scale. It is not for nothing that the field's name contains the word 'story'; the story must be as true as it can be, but do not expect it to yield any patterns.

Attempts at pattern-finding during the nineteenth and early twentieth centuries by Karl Marx, Oswald Spengler and Arnold Toynbee, for example - are seen as cautionary failures. There are world-systems theorists today, but they are few and marginalized. There are cliometricians, who present the particulars in quantitative form, but they are unlikely to generalize. Most historians don't want to measure Clio, the muse of history - they want her to inspire them to tell the best and truest story.

Anthropologists are different. Some at least have always sought patterns, and in surveying the great array of cultural variation that archaeology has unearthed and ethnography revealed, they have found them. Patterns have cropped up in some basic textbooks for decades. For example, in Culture, People, Nature (Longman, 1993), Marvin Harris calls the New World "the Second Earth", and presents facts about the independent rise of agriculture, cities and empires as the results of a natural experiment: what happens if we start with huntergatherers and run the tape again? The results are remarkable. Do the Aztecs exactly replicate Sumer or Shang China? Of course not. But no one can come away from the comparison without the sense that, at the broadest level, there are laws of history.

In the modern period, not all historians have shied away from cause-and-effect relations. William McNeill, for example, in his respected Plagues and Peoples (Penguin, 1979), showed history to be shaped by epidemics, and his history of the West takes seriously the effects of demographic, environmental and technological forces.

Michael Cook takes this process further. A Brief History of the Human Race begins geologically, using data from the Greenland ice core to show that the past 12,000 years

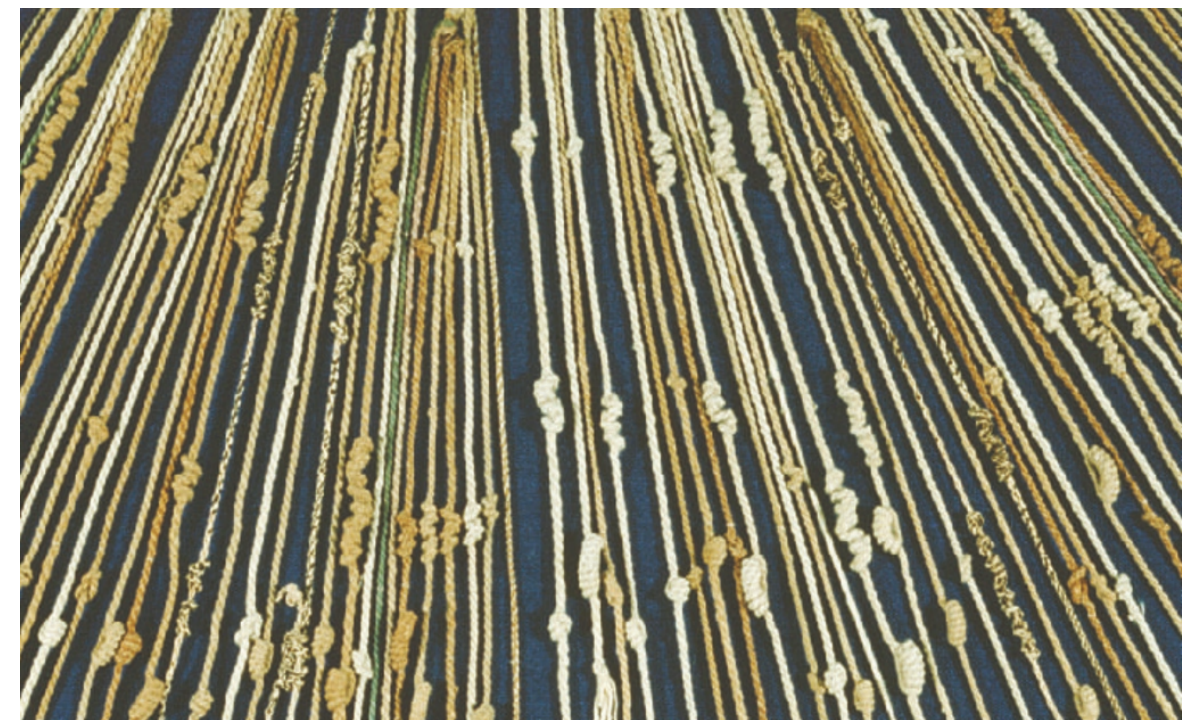

Strands of time? The Incas used a knotted rope called a quipu to keep historical records.

have seen a climate both warmer and more stable than in the preceding 100,000 years at least. This, he argues, made history - the change from a hunter-gatherer world to ours - possible. He proceeds biologically, showing that those 100,000 years correspond roughly to the spread of modern humans out of Africa. His summary of the DNA findings on this process leads to a conclusion widely accepted in anthropology: the human species as we know it is quite new and therefore remarkably unified.

One consequence is that humans respond similarly to the challenges and chances that geology and geography afford them. All human groups have wanted to do well, and many have had the ambition to build, grow and change. But the way they did it depended on where they were. Cook devotes considerable attention to Earth history, using descriptions of the collision of tectonic plates, the smoothing over of mountains, and the rise and fall of oceans, to set the scene for each continent's historical drama. Next, he reviews the peopling of the regions, using the best available genetic and archaeological evidence. He goes on to explain many aspects of regional history by reference to each region's geology, ecology and climate.

Technological innovation, predictably, has a central role thereafter. Stone was replaced by copper, copper by bronze, and bronze by iron in many parts of the world because humans want to do things better, and if the environment or trade networks afford them the opportunity, they will discover and apply new technological knowledge. Anomalies in this regard — some New Guinea groups who never left stone behind, or the absence of large domesticated animals in North American civilization — are attributed to limited ecological opportunities or geographical barriers to communication with other groups.

The book is anthropological in another sense: Cook presents vivid accounts of an important aspect of culture for each region in a way that is unusual in history books. Thus we find considerable detail on the Incan quipu, a record-keeping device in knotted rope; on the intricate clan and marriage rules of the Aranda hunter-gatherers of Australia; and on the sexually charged religious writings of India. These illustrate such general human tendencies as the need to keep account of things, the desire to order the social world, and the impulse to both express and control sexual drive.

By contrast, remarkably little attention is given to the past few centuries, which are covered in fewer than 30 pages. Perhaps this is appropriate. In a short history of the human species, many hard choices must be made, and Cook has focused on changes between the hunter-gatherer phase and the Industrial Revolution. Perhaps by that time the patterns were so well established that they could not be expected to change radically. But is hard to justify skipping the invention of democracy, our new power to destroy life on Earth, and the recent revolution in communication, while writing in detail about the quipu - however much it may warm an anthropologist's heart.

Another omission from the book - as from most history books - is any account of the human players in this great historical drama as individual members of a species, with shared tendencies and behaviours. The book is full of large-scale violence in the 
service of competition and ambition, but it makes no explicit reference to the possibility that part of the explanation lies in human nature. There are many entertaining references to sex, but none to the reproductive imperative that makes sex so exceptionally interesting.

Still, this is a particularly good history for a scientist to read, devoting as it does much more time and effort to underlying material causes than has been traditional. It is an elegant, quick and engaging way to review what has happened in history, to learn much that is new, and to appreciate the past of the whole world, not just the West. It meets scientists almost halfway, trying to ground the events of history literally in the material facts of the planet. As Cook understands, the best and truest story of our experience on Earth is in part a scientific one. Clio, I think, is smiling.

Melvin Konner is in the Department of Anthropology, Emory University, Atlanta, Georgia 30322, USA. He is the author of The Tangled Wing: Biological Constraints on the Human Spirit, revised edition.

\section{Sowing seeds of discontent}

\section{So Shall We Reap}

by Colin Tudge

Allen Lane: 2003.380 pp. $£ 20$

\section{Anthony Trewavas}

A common method of political and religious persuasion is to dwell on the virtues of belief for the follower and damnation for the unbeliever. Science writer Colin Tudge uses the same approach in this book, which is devoted to what he calls 'enlightened agriculture'. The prospects for humanity "are somewhere between glorious and dire", we are told; glorious if you follow Tudge's proscriptions, hell if you don't. The book's subtitle hammers this home: "How everyone who is liable to be born in the next ten thousand years could eat very well indeed; and why, in practise, our immediate descendants are likely to be in serious trouble". And as if to emphasize the religious origin of such dichotomous futures for humans, the book is liberally spiced with biblical quotations.

Tudge regards food production as something that should be above the ordinary, grubby business of economics. He regards capitalism as acceptable provided it doesn't involve competition! He sees a future in which most of us return to the rustic idyll, happily tilling the land - although he does not say who will generate the cash to pay for education or health, or the other trinkets we have got used to and that people enjoy. Whether any of us want to return to that way

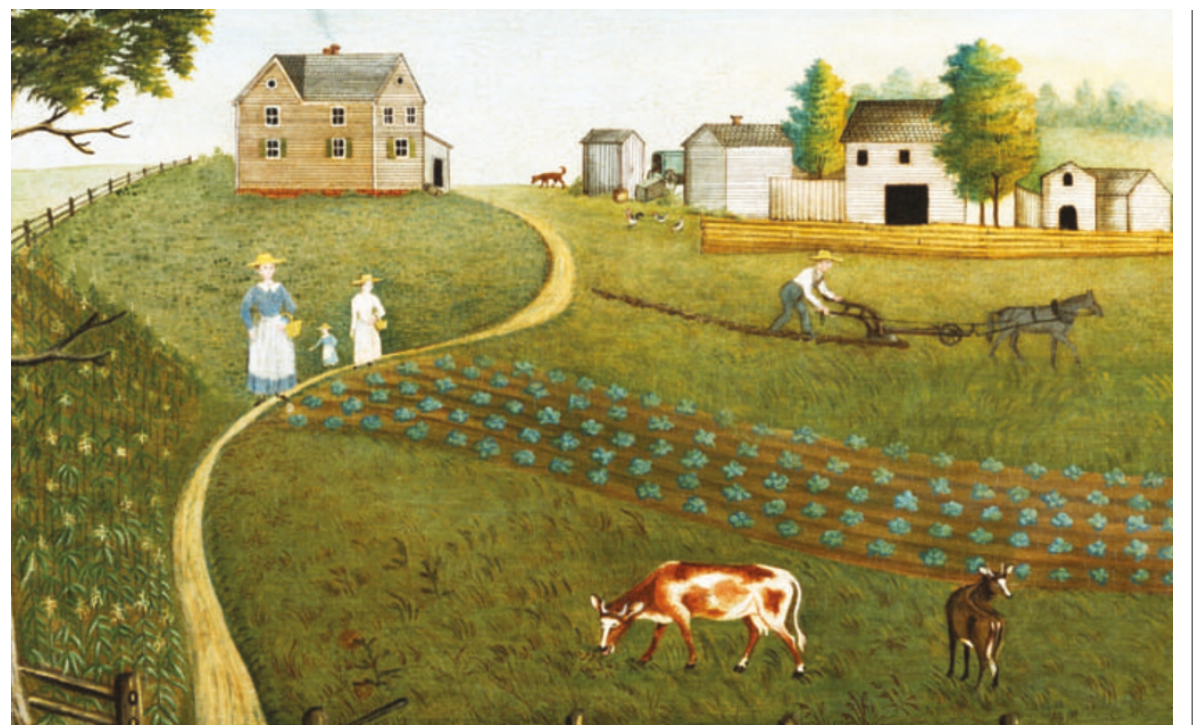

Cultivating a dream: do today's economic realities stop us returning to the rural idyll?

of life is not considered. And because it is generally agreed that there isn't much money to be made in farming, the prospects for most of us do not look good.

Antipathy to economics is common among those of Tudge's persuasion, but unless fine-sounding sentiments are properly underpinned with an understanding of economics, immense damage can result. It has been estimated that for every $1 \%$ increase in income, mortality is reduced by $0.05 \%$. The converse is equally the case. Scepticism about the motives of large global agribusiness is reasonable, but assuming that they are populated with shadowy figures out to control the world's food supply is not. Most UK citizens (probably including Tudge) invest heavily in the success of such enterprises through pensions and other financial plans. From Malthus onwards, the history of agricultural prediction has been a history of failure. Tudge's poorly based views will probably fare no better.

In Western countries a few decades ago, agricultural policy was simple. Production was all that was needed, and objective knowledge (science) was wheeled in to ensure its success. But abundance has produced new problems. Food security is no longer an issue, although rapid global cooling could quickly push it up the agenda. Instead, agriculture and, in Britain at least, the inevitable intermingling with the environment, have become contentious moral affairs. These are now areas of subjective knowledge in which disagreement, which merely reflects individual taste, is inevitable. Tudge claims that biology is the basis of his book, but chapters covering such issues as morality, aesthetics, genetically modified (GM) organisms, cash and values belie the claim.

It is a pity that authors such as Tudge and most environmentalists do not talk to farmers, as a more realistic appraisal might then surface. Farmers could tell them about responsible farming based on integrated management, conservation agriculture and animal-welfare principles, but also about the necessary business of running the farm at a profit. For the public, competition produces cheap fruit and vegetables, and by thus encouraging consumption has produced a healthier population with lower cancer rates. Tudge is more objective on organic farming and sees the regulations of this movement as dogma rather than common sense.

Tudge reserves his venom for GM crops, condemning the scientists who produce such "monstrosities" as obviously corrupt, as well as mad, bad and dangerous. I found this chapter to be a muddle of politics and naturalism, failing to adequately distinguish objective scientific knowledge from subjective assessments of Western agribusiness and nature.

Vitamin A deficiency in developing countries results in the premature death of about a million children a year and leaves another five million permanently blind. The primary reason for this situation, according to the World Health Organization, is poverty and ignorance about vitamins and diet. But Tudge claims instead that recent Western agricultural influences are the cause, as if these deficiencies did not happen in much earlier times. GM rice enriched with vitamin A to help counter this deficiency is a humanitarian scientific endeavour that demonstrates how valuable GM technology can be in improving life expectancy in the face of ignorance.

Tudge also fails to mention that both India and China now have proven examples of the benefits of GM crops to poor farmers. Herbicide-tolerant GM crops (produced by agribusiness) lead naturally to no-till agriculture, which has enormous environmental advantages over any kind of ploughed agriculture, including organic farming. These benefits are likewise not mentioned. GM 